\title{
Research on the optimization method of selecting hearing protectors in power station
}

\author{
Quanquan Gong ${ }^{1}$, Lianke Xie ${ }^{2}$, Dandan Dou ${ }^{3}$, Guoying Zhang ${ }^{4}$, Kun Wang ${ }^{5}$ Jiamei Zhao ${ }^{6}$ \\ $1,2,3,4,5$ State Grid Shandong Electric Power Research Institute of the Institution, Ji'nan, Shandong, China \\ ${ }^{6}$ Beijing Municipal Institute of Labour Protection, Beijing, China \\ ${ }^{6}$ Corresponding author \\ E-mail: 161908056@qq.com, ${ }^{2} 40585552 @ q q . c o m,{ }^{3} 157265423 @ q q . c o m,{ }^{4} 250212650 @ q q . c o m$, \\ 5604195719@qq.com, ${ }^{6}$ gamay_jy@163.com
}

Received 13 April 2020; accepted 24 April 2020

DOI https://doi.org/10.21595/vp.2020.21417

Check for updates

Copyright $(C 2020$ Quanquan Gong, et al. This is an open access article distributed under the Creative Commons Attribution License, which permits unrestricted use, distribution, and reproduction in any medium, provided the original work is properly cited.

\begin{abstract}
In order to explore the noise reduction effect and application of different hearing protectors in different workplaces in a power station, so as to facilitate to select differently suitable hearing protectors to staff based on needs. This paper uses principal component analysis and evaluation according to the insertion loss test results of 112 kinds of hearing protectors. Combined with the field test results of 10 workplaces in a power station, it is found that 112 kinds of hearing protectors mostly are suitable in 7 working places. People need to select suitable hearing protectors specifically in other 3 places. At the same time, this paper can provide reference for the selection of hearing protection in other different working places.
\end{abstract}

Keywords: power station, hearing protectors, principal component analysis.

\section{Introduction}

With the deepening of reform and opening up and the rapid development of the national economy, the construction of power station has also entered a period of rapid development. Because the power station has the characteristics of high water head, large capacity, high speed of the unit, two-way operation of water flow and changing frequency of working conditions, the noise is quite obvious, which will have a great impact on the personnel working in the factory area. Long-term work is highly likely to lead to permanent hearing loss and even severe occupational deafness in a high-noise environment without effective protection $[1,2]$. At present, many countries have listed occupational deafness as one of the important occupational diseases $[3,4]$. Therefore, people working in the high noise area of power station need hearing protection to avoid the risk of hearing loss. In this paper, we tested the insertion loss of 112 kinds of hearing protectors on the market, then we picked out the more suitable hearing protectors in 10 kinds of workplaces in the power station using principal component analysis method. At present, there are many kinds of hearing protectors that can be purchased, workers have some confusion when choosing them, and they often cannot find the most suitable hearing protectors. In order to help workers make the best choice according to the needs of the workplace and protect their hearing, this research work has been carried out.

\section{Characteristics and analysis of power station noise}

In this paper, there are different workplaces in this power station, the environment noise is measured separately in order to fully understand the noise situation of power station and select the best noise protection equipment. The noise exposure value in the working place is mainly measured, and the test time is from March 21th to March 23th in 2018. Under the operating condition of each unit, the ventilation facilities should operate normally. The noise level of the operating condition of each unit are shown in Table 1.

From Table 1, it can be seen that there are 10 testing places which are more than $85 \mathrm{dBA}$. The spectrum measurement and analysis of the 10 workplaces under operating conditions are shown in Fig. 1. 
Table 1. The noise level of the operating condition of each unit

\begin{tabular}{|c|c|c|c|c|c|c|c|}
\hline No. & Workplaces & Testing places & $\mathrm{dB}(\mathrm{A})$ & No. & Places & Points & $\mathrm{dB}(\mathrm{A})$ \\
\hline 1 & \multirow{6}{*}{$\begin{array}{l}\text { Generator } \\
\text { layer }\end{array}$} & $\begin{array}{c}\text { \#1 Generator } \\
\text { layer }\end{array}$ & 78.4 & 18 & \multirow{6}{*}{$\begin{array}{l}\text { Water turbine } \\
\text { layer }\end{array}$} & $\begin{array}{c}\text { \#1 Outdoor } \\
\text { water turbine }\end{array}$ & 85.2 \\
\hline 2 & & $\begin{array}{l}\text { \#1 Generator } \\
\text { interior }\end{array}$ & 94.6 & 19 & & $\begin{array}{l}\text { \#1 Indoor water } \\
\text { turbine }\end{array}$ & 93.6 \\
\hline 3 & & $\begin{array}{c}\# 2 \text { Generator } \\
\text { layer }\end{array}$ & 77.3 & 20 & & $\begin{array}{l}\text { \#2 Outdoor } \\
\text { water turbine }\end{array}$ & 84.8 \\
\hline 4 & & $\begin{array}{c}\# 3 \text { Generator } \\
\text { layer }\end{array}$ & 76.8 & 21 & & $\begin{array}{l}\text { \#2 Indoor water } \\
\text { turbine }\end{array}$ & 93.7 \\
\hline 5 & & $\begin{array}{c}\# 4 \text { Generator } \\
\text { layer }\end{array}$ & 72.3 & 22 & & $\begin{array}{l}\text { \#3 Outdoor } \\
\text { water turbine }\end{array}$ & 83.2 \\
\hline 6 & & Installing room & 68.9 & 23 & & $\begin{array}{c}\text { \#3 Indoor water } \\
\text { turbine }\end{array}$ & 91.5 \\
\hline 7 & \multirow{4}{*}{$\begin{array}{l}\text { Wind tunnel } \\
\text { layer }\end{array}$} & $\begin{array}{l}\text { \#1 Outdoor } \\
\text { wind tunnel }\end{array}$ & 82.6 & 24 & \multirow{3}{*}{$\begin{array}{l}\text { Main electrical } \\
\text { wire Hall }\end{array}$} & $\begin{array}{c}\text { \#1 Main } \\
\text { electrical wire } \\
\text { hall }\end{array}$ & 79.8 \\
\hline 8 & & $\begin{array}{l}\text { \#2 Outdoor } \\
\text { wind tunnel }\end{array}$ & 84.2 & 25 & & $\begin{array}{c}\text { \#2 Main } \\
\text { electrical wire } \\
\text { hall }\end{array}$ & 76.0 \\
\hline 9 & & $\begin{array}{l}\text { \#3 Outdoor } \\
\text { wind tunnel }\end{array}$ & 83.7 & 26 & & $\begin{array}{c}\text { \#3 Main } \\
\text { electrical wire } \\
\text { hall } \\
\end{array}$ & 76.1 \\
\hline 10 & & $\begin{array}{l}\text { \#4 Outdoor } \\
\text { wind tunnel }\end{array}$ & 81.7 & 27 & \multirow{8}{*}{$\begin{array}{l}\text { Transformer } \\
\text { chamber }\end{array}$} & $\begin{array}{c}\text { \#1 Transformer } \\
\text { chamber }\end{array}$ & 82.7 \\
\hline 11 & \multirow{7}{*}{ Volute layer } & $\begin{array}{c}\text { \#1 Outdoor } \\
\text { draft tube cone }\end{array}$ & 82.9 & 28 & & $\begin{array}{c}\text { \#2 Transformer } \\
\text { chamber }\end{array}$ & 84.7 \\
\hline 12 & & $\begin{array}{l}\# 1 \text { Indoor draft } \\
\text { tube cone }\end{array}$ & 84.4 & 29 & & $\begin{array}{c}\text { \#3 Transformer } \\
\text { chamber }\end{array}$ & 85.5 \\
\hline 13 & & $\begin{array}{c}\# 2 \text { Outdoor } \\
\text { draft tube cone }\end{array}$ & 85.1 & 30 & & Cable interlayer & 72.0 \\
\hline 14 & & $\begin{array}{l}\text { \#2 Indoor draft } \\
\text { tube cone }\end{array}$ & 87.9 & 31 & & SFC room & 70.7 \\
\hline 15 & & $\begin{array}{c}\text { \#3 Outdoor } \\
\text { draft tube cone }\end{array}$ & 85.5 & 32 & & LCU room & 68.2 \\
\hline 16 & & $\begin{array}{l}\text { \#3 Indoor draft } \\
\text { tube cone }\end{array}$ & 88.7 & 33 & & $\begin{array}{l}\text { LCU switching } \\
\text { room }\end{array}$ & 65.0 \\
\hline 17 & & $\begin{array}{l}\text { \#4 Ball valve } \\
\text { area }\end{array}$ & 84.7 & 34 & & GIS room & 71.0 \\
\hline
\end{tabular}

\section{Selection of hearing protections}

\subsection{Preliminary screening of hearing protectors}

We tested 112 kinds of hearing protectors insertion loss, they are all selected randomly from the market. During the test, we referred to the following standards: ISO 4869-3:2007 "Acoustics-Hearing protectors - Part 3: Measurement of insertion loss of ear-muff type protectors using an acoustic test fixture" and ISO 4859-2:1994 "Acoustics-Hearing protectors - Part 2: Estimation of effective A-weighted sound pressure levels when hearing protectors are worn" $[5,6]$.

We tested using the instruments by B\&K 4128C Head and Torso Simulators, using the pink noise as the noise source. The sound pressure levels were tested with [1] the hearing protector and without the hearing protector, respectively. The results of errors are insertion loss, that is:

$L_{l, A e q}=10 \log \sum_{i=1}^{33} 10^{\left(L_{p, i}-L_{e, i}\right) / 10}$, 
where $L_{l, A e q}$ is the equivalent continuous A-weighted sound pressure level after wearing hearing protectors when workplaces are tested. $L_{p, i}$ is the actual test of each frequency band sound level in different workplaces. $L_{e, i}$ is the insertion loss of each frequency band sound level of different kinds of hearing protectors, $i$ is 33 frequency bands.

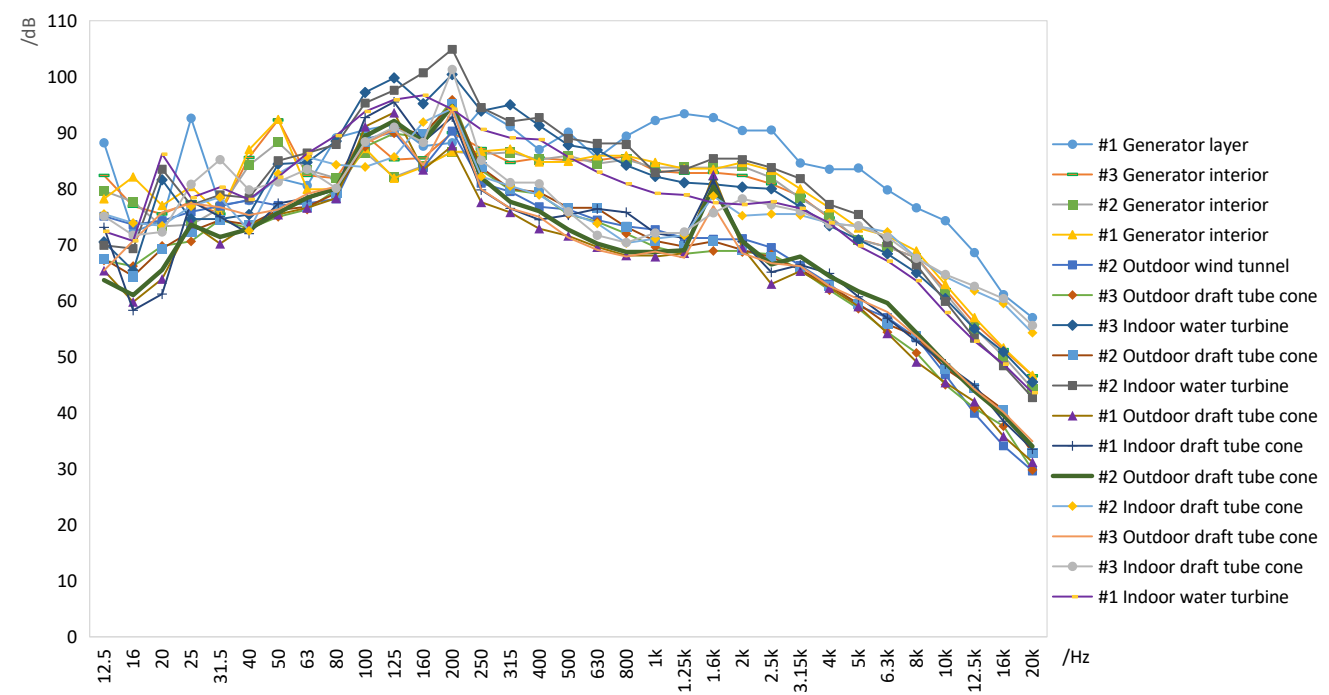

Fig. 1. The spectrum of $1 / 3$ octave of noise in 10 working places

The steps of testing are:

(1) The sound pressure level at the microphone is tested using PLUSE 7758 when Head and Torso Simulators are not inserted the hearing protector.

(2) Place the hearing protectors in the Head and Torso Simulators' ear canal in sequence, and ensure the hearing protectors is located in the center of the microphone (as shown in Fig. 2).

(3) After about $30 \mathrm{~s}$, the sound pressure level is tested again using PLUSE 7758 when Head and Torso Simulators are inserted the hearing protector.

(4) Repeat steps (1)-(3) three times with the same hearing protectors, the average value of three times is used to calculate the insertion loss.
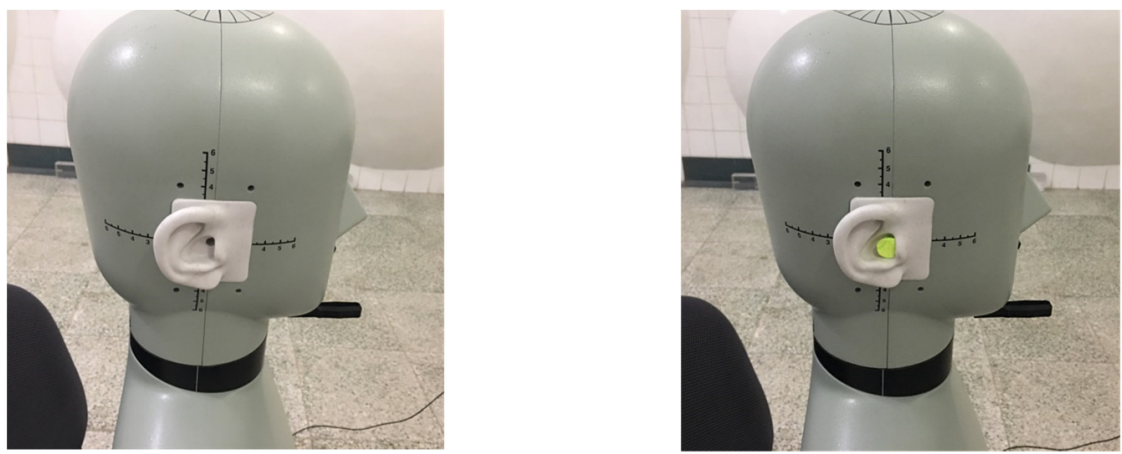

Fig. 2. The contrast of before and after hearing protectors insertion

The equivalent continuous A-weighted sound pressure level can be obtained by weighting the insertion loss of each frequency band. Based on GB/T 23466-2009 "Guidelines for selection of hearing protectors", the effective value of the weighted sound pressure level is between $75 \mathrm{~dB}(\mathrm{~A})-80 \mathrm{~dB}(\mathrm{~A})$ after the operator is protected by the hearing protector. While less than $70 \mathrm{~dB}(\mathrm{~A})$ indicates that the hearing protectors are overprotective, and the more than $80 \mathrm{~dB}(\mathrm{~A})$ are 
lack of protection [4]. The Eq. (1) is used to calculate the equivalent continuous A-weighted sound pressure level with hearing protectors in each test place. There are 24 kinds of hearing protectors, the equivalent continuous A-weighted sound pressure level are between $75 \mathrm{~dB}(\mathrm{~A})-80 \mathrm{~dB}(\mathrm{~A})$ after wore, as shown in Table 2.

Table 2. The better testing results of different brands in the different workplaces

\begin{tabular}{|c|c|c|}
\hline No. & testing places & The better testing results of the Brands \\
\hline 1 & $\begin{array}{l}\# 1 \text { generator } \\
\text { interior }\end{array}$ & $\begin{array}{c}\text { Lian Zhi Pi, 3M, Quies, Deltaplus-conifit, Shi Da, Xing Gong, Nan Ji Ren, } \\
\text { Black Forest Soft, Mack's-aqua-block, De Bei Nuo, Ju Li, Jin Xiu Yue Dian, } \\
\text { Mei Bai }\end{array}$ \\
\hline 2 & $\begin{array}{c}\text { \#1 outdoor } \\
\text { water turbine }\end{array}$ & Shi Da, Xing Gong \\
\hline 3 & $\begin{array}{l}\text { \#1 indoor water } \\
\text { turbine }\end{array}$ & $\begin{array}{c}\begin{array}{c}\text { Venitex-conicfit06, Lian Zhi Pi, Quies, Deltaplus-conifit, Sai Er Bi, Ju Jia Jia, } \\
\text { Pluggerz-sleep }\end{array} \\
\end{array}$ \\
\hline 4 & $\begin{array}{l}\text { \#2 indoor water } \\
\text { turbine }\end{array}$ & $\begin{array}{c}\text { Venitex-conicfit06, Lian Zhi Pi, Quies, Deltaplus-conifit, Ohropax-color, } \\
\text { Ohropax-mini-soft, Ohropax-classic, Mack's, Nan Ji Ren, Mack's-earammo, } \\
\text { Ju Jia Jia, Ju Li, Jin Xiu Yue Dian, Pluggerz-diy, Mei bai }\end{array}$ \\
\hline 5 & $\begin{array}{l}\text { \#3 indoor water } \\
\text { turbine }\end{array}$ & $\begin{array}{l}\text { Venitex-conicfit06, Lian Zhi Pi, Quies, Deltaplus-conifit, Ohropax-color, } \\
\text { Ohropax-mini-soft, Shi Da, Ohropax-classic, Mack's, Nan Ji Ren, Mack’s- } \\
\text { earammo, Ju Jia Jia, Ju Li, Jin Xiu Yue Dian, Mei Bai }\end{array}$ \\
\hline 6 & $\begin{array}{c}\# 2 \text { outdoor } \\
\text { draft tube cone }\end{array}$ & Shi Da, Xing Gong, Sai Er Bi \\
\hline 7 & $\begin{array}{l}\# 2 \text { indoor draft } \\
\text { tube cone }\end{array}$ & Lian Zhi Pi, Quies, Xing Gong, Sai Er Bi, Pluggerz-sleep \\
\hline 8 & $\begin{array}{l}\text { \#3 outdoor } \\
\text { draft tube cone }\end{array}$ & Shi Da, Xing Gong, Sai Er Bi \\
\hline 9 & $\begin{array}{l}\# 3 \text { indoor draft } \\
\text { tube cone }\end{array}$ & Xing Gong, Sai Er Bi \\
\hline 10 & $\begin{array}{l}\text { \#3 transformer } \\
\text { chamber }\end{array}$ & - \\
\hline
\end{tabular}

\subsection{Statistical analysis}

Principal component analysis (PCA) is a multivariate statistical method that transforms multiple indexes into a few comprehensive indexes based on the idea of dimensionality and the principle of minimizing the loss of data information [7].

In this paper, the insertion loss of each central frequency band of 24 kinds of hearing protectors is analyzed by PCA method, as shown in Table 3 and Table 4.

Table 3. Communalities

\begin{tabular}{|c|c|c|}
\hline Frequency & Initial & Extraction \\
\hline $31.5 \mathrm{~Hz}$ & 1.000 & 0.783 \\
\hline $63 \mathrm{~Hz}$ & 1.000 & 0.772 \\
\hline $125 \mathrm{~Hz}$ & 1.000 & 0.937 \\
\hline $250 \mathrm{~Hz}$ & 1.000 & 0.952 \\
\hline $500 \mathrm{~Hz}$ & 1.000 & 0.940 \\
\hline $1000 \mathrm{~Hz}$ & 1.000 & 0.910 \\
\hline $2000 \mathrm{~Hz}$ & 1.000 & 0.940 \\
\hline $4000 \mathrm{~Hz}$ & 1.000 & 0.853 \\
\hline $8000 \mathrm{~Hz}$ & 1.000 & 0.641 \\
\hline $16000 \mathrm{~Hz}$ & 1.000 & 0.612 \\
\hline
\end{tabular}


Table 4. Total variance explained

\begin{tabular}{|c|c|c|c|c|c|c|}
\hline \multirow{2}{*}{ Component } & \multicolumn{5}{|c|}{ Initial eigenvalues } & \multicolumn{3}{c|}{ Extraction sums of squared loading } \\
\cline { 2 - 7 } & Total & \% of variance & Cumulative \% & Total & \% of variance & Cumulative \% \\
\hline 1 & 6.990 & 69.899 & 69.899 & 6.990 & 69.899 & 69.899 \\
\hline 2 & 1.349 & 13.492 & 83.391 & 1.349 & 13.492 & 83.391 \\
\hline 3 & .636 & 6.361 & 89.752 & & & \\
\hline 4 & .426 & 4.265 & 94.017 & & & \\
\hline 5 & .254 & 2.540 & 96.557 & & & \\
\hline 6 & .207 & 2.067 & 98.623 & & & \\
\hline 7 & .087 & .868 & 99.492 & & & \\
\hline 8 & .028 & .282 & 99.774 & & & \\
\hline 9 & .014 & .135 & 99.909 & & & \\
\hline 10 & .009 & .091 & 100.00 & & & \\
\hline
\end{tabular}

According to Table 3, it can be obtained that the principal component coefficients extracted in each frequency band are all more than 0.5 , which indicates that the extracted principal components have a higher degree of interpretation of each variable. According to Table 4, two principal components were extracted in this calculation analysis. The characteristic root of the first principal component is 6.990 , the variance contribution rate is $69.899 \%$. And the characteristic root of the second principal component is 1.349 , the variance contribution rate is $13.492 \%$. The cumulative variance contribution rate of the two principal components is $83.391 \%$. It is further indicated that the extraction of the two principal components is appropriate.

Table 5. Component matrix*

\begin{tabular}{|c|c|c|c|c|c|}
\hline \multirow{2}{*}{ Frequency } & \multicolumn{2}{|c|}{ Component } & \multirow{2}{*}{ Frequency } & \multicolumn{2}{c|}{ Component } \\
\cline { 2 - 5 } & 1 & 2 & & 1 & 2 \\
\hline $31.5 \mathrm{~Hz}$ & -0.055 & 0.883 & $1000 \mathrm{~Hz}$ & 0.936 & -0.185 \\
\hline $63 \mathrm{~Hz}$ & -0.856 & 0.200 & $2000 \mathrm{~Hz}$ & 0.968 & -0.061 \\
\hline $125 \mathrm{~Hz}$ & 0.967 & 0.036 & $4000 \mathrm{~Hz}$ & 0.906 & 0.180 \\
\hline $250 \mathrm{~Hz}$ & 0.956 & -0.196 & $8000 \mathrm{~Hz}$ & 0.800 & -0.026 \\
\hline $500 \mathrm{~Hz}$ & 0.952 & -0.186 & $16000 \mathrm{~Hz}$ & 0.477 & 0.620 \\
\hline$* 2$ components extracted \\
\hline
\end{tabular}

As shown in Table 5, the correlation coefficient between the first principal component and frequencies from $63 \mathrm{~Hz}$ to $8000 \mathrm{~Hz}$ are all close to 1, this indicate that there are more hearing protectors with noise reduction range from $63 \mathrm{~Hz}$ to $8000 \mathrm{~Hz}$ in the tested hearing protectors. Similarly, there are more hearing protectors with noise reduction range with frequency bands of $31.5 \mathrm{~Hz}$ and $16000 \mathrm{~Hz}$ in the second principal component.

Each principal component can be weighted and summed according to the characteristic root of each principal component:

$F=\left[u_{1} /\left(u_{1}+u_{2}\right)\right] \times F_{1}+\left[u_{2} /\left(u_{1}+u_{2}\right)\right] \times F_{2}$,

where $F_{1}$ and $F_{2}$ are two principal component functions respectively, $u_{1}$ and $u_{2}$ the characteristic roots of the two principal components respectively. According to Eq. (2), the ranking of principal component score and comprehensive score of 24 kinds of hearing protectors can be determined, as shown in Table 6.

We can see from the Table 6 that in the comparison of each brand of hearing protection in this study, the hearing protection of Xing Gong brand is more representative among $63-8000 \mathrm{~Hz}$, and Pluggerz-sleep brand's hearing protection is more representative in $31.5 \mathrm{~Hz}$ and $16000 \mathrm{~Hz}$.

Combined with the above principal component analysis, it can be concluded that among the 112 kinds of hearing protection devices tested, most of the hearing protection devices are more suitable for the 7 sites studied: \#1 generator layer, \#1 outdoor water turbine, \#1 indoor water 
turbine, \#2 outdoor draft tube cone, \#2 indoor draft tube cone, \#3 outdoor draft tube cone and \#3 indoor draft tube cone.

Table 6. The ranking of principal component score and comprehensive score of 24 kinds of hearing protectors

\begin{tabular}{|c|c|c|c|c|c|c|c|}
\hline Brands & $\begin{array}{c}\text { Rank the } \\
\text { score of } \\
\text { principal } \\
\text { component } \\
1\end{array}$ & $\begin{array}{c}\text { Rank the } \\
\text { score of } \\
\text { principal } \\
\text { component } \\
2\end{array}$ & $\begin{array}{c}\text { Rank the } \\
\text { comprehensive } \\
\text { score }\end{array}$ & Brands & $\begin{array}{c}\text { Rank the } \\
\text { score of } \\
\text { principal } \\
\text { component } \\
1\end{array}$ & \begin{tabular}{|c} 
Rank the \\
score of \\
principal \\
component \\
2
\end{tabular} & $\begin{array}{c}\text { Rank the } \\
\text { comprehensive } \\
\text { score }\end{array}$ \\
\hline $\begin{array}{l}\text { Venitex- } \\
\text { conicfit06 }\end{array}$ & 5 & 24 & 9 & $\begin{array}{c}\text { Black } \\
\text { Forest- } \\
\text { soft }\end{array}$ & 20 & 10 & 20 \\
\hline $\begin{array}{c}\text { Lian Zhi } \\
\text { Pil\# }\end{array}$ & 7 & 18 & 8 & $\begin{array}{c}\text { Mack's- } \\
\text { aquablock }\end{array}$ & 14 & 13 & 13 \\
\hline $3 \mathrm{M}-1270$ & 16 & 21 & 16 & $\begin{array}{c}\text { De Bei } \\
\text { Nuo }\end{array}$ & 24 & 7 & 24 \\
\hline Quies & 4 & 9 & 4 & \begin{tabular}{|c|}
$\begin{array}{c}\text { Mack's- } \\
\text { earammo }\end{array}$ \\
\end{tabular} & 18 & 12 & 18 \\
\hline $\begin{array}{c}\text { Deltaplus- } \\
\text { conifit }\end{array}$ & 3 & 23 & 6 & Sai Er Bi & 8 & 8 & 5 \\
\hline $\begin{array}{c}\text { Ohropax- } \\
\text { color }\end{array}$ & 23 & 15 & 23 & Ju Jia Jia & 15 & 6 & 14 \\
\hline $\begin{array}{l}\text { Ohropax- } \\
\text { mini-soft }\end{array}$ & 22 & 14 & 22 & $\mathrm{Ju} \mathrm{Li}$ & 12 & 16 & 10 \\
\hline Shi Da & 2 & 11 & 2 & \begin{tabular}{|c|} 
Jin Xiu \\
Yue Dian \\
\end{tabular} & 10 & 22 & 12 \\
\hline $\begin{array}{l}\text { Xing } \\
\text { Gong }\end{array}$ & 1 & 3 & 1 & \begin{tabular}{|c|} 
Pluggerz- \\
Sleep
\end{tabular} & 6 & 1 & 3 \\
\hline $\begin{array}{c}\text { Ohropax- } \\
\text { classic }\end{array}$ & 13 & 20 & 15 & $\begin{array}{c}\text { Pluggerz- } \\
\text { diy }\end{array}$ & 9 & 2 & 7 \\
\hline Mack's & 11 & 19 & 11 & Mei Bai & 21 & 4 & 21 \\
\hline $\begin{array}{c}\text { Nan Ji } \\
\text { Ren }\end{array}$ & 19 & 5 & 19 & \begin{tabular}{|c} 
Lian Zhi \\
Pi2\#
\end{tabular} & 17 & 17 & 17 \\
\hline
\end{tabular}

\section{Conclusions}

According to the test analysis in this paper, it can be seen that the working environment and noise intensity of the power station are different. In the 10 of the 34 sites tested, the noise is too high, which is not conducive to workers' work and affects the physical and mental health of workers, so it is necessary to effectively protect the situation.

By testing the insertion loss of 112 kinds of hearing protectors, 24 kinds of hearing protectors with better noise reduction effect were selected. The principal component analysis of the 24 kinds of hearing protectors were carried out and find out the most representative hearing protectors. Most of the 112 kinds of hearing protectors tested are suitable for the 7 workplaces. The other 3 workplaces need to be targeted to choose the suitable hearing protectors. This study also provides a reference for other workplaces to choose the type of hearing protectors.

\section{References}

[1] Wang Runlan, Liu Shufeng, Cheng Suxuan Problems and countermeasures of protective measures against occupational noise deafness. Journal of Diseases Monitor and Control, Vol. 7, Issue 7, 2013, p. $443-444$. 
[2] Shi Lei, Zhang Xing Research progress on effects of noise on human health. China Occupational Medicine, Vol. 42, Issue 2, 2015, p. 225-228.

[3] Yan Zhi Occupational noise hazard and control. Modern Occupational Safety, Vol. 8, 2008, p. 96.

[4] Whittaker J. D., Robinson T., Acharya A., Singh D., Smith M. Noise-induced hearing loss in small-scale metal industry in Nepal. The Journal of Laryngology and Otology, Vol. 128, Issue 10, 2014, p. 871-880.

[5] ISO 4869-3: 2007. Acoustics-Hearing Protectors - Part 3: Measurement of Insertion Loss of Ear-Muff Type Protectors Using an Acoustic Test Fixture, 2007.

[6] ISO 4859-2:1994. Acoustics-Hearing Protectors - Part 2: Estimation of Effective A-Weighted Sound Pressure Levels When Hearing Protectors Are Worn, 1994.

[7] Wang Donghua Multivariate Statistical Analysis and SPSS Application. Shanghai, 2016. 